\title{
Islet beta cell failure in the $60 \%$ pancreatectomised obese hyperlipidaemic Zucker fatty rat: severe dysfunction with altered glycerolipid metabolism without steatosis or a falling beta cell mass
}

\author{
V. Delghingaro-Augusto • C. J. Nolan • D. Gupta • \\ T. L. Jetton • M. G. Latour • M. Peshavaria • \\ S. R. Murthy Madiraju • É. Joly • M.-L. Peyot • \\ M. Prentki • J. Leahy
}

Received: 21 November 2008 / Accepted: 7 January 2009/Published online: 18 March 2009

(C) Springer-Verlag 2009

\begin{abstract}
Aims/hypothesis The Zucker fatty (ZF) rat subjected to $60 \%$ pancreatectomy (Px) develops moderate diabetes by 3 weeks. We determined whether a progressive fall in beta cell mass and/or beta cell dysfunction contribute to beta cell failure in this type 2 diabetes model.

Methods Partial (60\%) or sham Px was performed in ZF and Zucker lean (ZL) rats. At 3 weeks post-surgery, beta cell mass and proliferation, proinsulin biosynthesis, pan-
\end{abstract}

M. Prentki and J. Leahy contributed equally to this work.

Electronic supplementary material The online version of this article (doi:10.1007/s00125-009-1317-8) contains supplementary material, which is available to authorised users.

V. Delghingaro-Augusto $\cdot$ M. G. Latour $\cdot$ S. R. M. Madiraju •

É. Joly $\cdot$ M.-L. Peyot $\cdot$ M. Prentki $(\bowtie)$

Molecular Nutrition Unit and

the Montreal Diabetes Research Center, CR-CHUM,

2901 Rachel Est,

Montreal, QC, Canada H1N 4A4

e-mail: marc.prentki@umontreal.ca

\section{J. Nolan}

Department of Endocrinology, The Canberra Hospital, and the Medical School, The Australian National University,

Garran, ACT, Australia

D. Gupta $\cdot$ T. L. Jetton $\cdot$ M. Peshavaria $\cdot$ J. Leahy

Division of Endocrinology, Diabetes and Metabolism,

University of Vermont,

Burlington, VT, USA creatic insulin content, insulin secretion, and islet glucose and lipid metabolism were measured.

Results ZL-Px rats maintained normal glycaemia and glucose-stimulated insulin secretion (GSIS) despite incomplete recovery of beta cell mass possibly due to compensatory enhanced islet glucose metabolism and lipolysis. ZF-Px rats developed moderate hyperglycaemia (14 mmol/l), hypertriacylglycerolaemia and relative hypoinsulinaemia. Despite beta cell mass recovery and normal arginine-induced insulin secretion, GSIS and pancreatic insulin content were profoundly lowered in ZF-Px rats. Proinsulin biosynthesis was not reduced. Compensatory increases in islet glucose metabolism above those observed in ZF-Sham rats were not seen in ZF-Px rats. Triacylglycerol content was not increased in ZF-Px islets, possibly due to lipodetoxification by enhanced lipolysis and fatty acid oxidation. Fatty acid accumulation into monoacylglycerol and diacylglycerol was increased in ZF-Px islets together with a 4.5-fold elevation in stearoyl-CoA desaturase mRNA expression.

Conclusions/interpretation Falling beta cell mass, reduced proinsulin biosynthesis and islet steatosis are not implicated in early beta cell failure and glucolipotoxicity in ZF-Px rats. Rather, severe beta cell dysfunction with a specific reduction in GSIS and marked depletion of beta cell insulin stores with altered lipid partitioning underlie beta cell failure in this animal model of type 2 diabetes.

Keywords Beta cell mass · Fatty acid metabolism . Glucolipotoxicity · Glycerolipid/fatty acid cycling · Insulin biosynthesis · Insulin resistance $\cdot$ Insulin secretion · Pancreatectomy Pancreatic islet $\cdot$ Zucker fatty rat 


$\begin{array}{ll}\text { Abbreviations } \\ \text { GL/FA } & \text { Glycerolipid/fatty acid } \\ \text { GIP } & \text { Glucose-dependent insulinotropic polypeptide } \\ \text { GLP-1 } & \text { Glucagon-like peptide-1 } \\ \text { GSIS } & \text { Glucose-stimulated insulin secretion } \\ \text { PKC } & \text { Protein kinase C } \\ \text { Px } & \text { Pancreatectomy } \\ \text { ZDF } & \text { Zucker diabetic fatty } \\ \text { ZF } & \text { Zucker fatty } \\ \text { ZL } & \text { Zucker lean }\end{array}$

\section{Introduction}

In obesity-associated type 2 diabetes, insulin secretion declines as normal glucose tolerance advances to overt hyperglycaemia [1-3]. Return to normoglycaemia through interventions such as reduced energy intake, use of insulin-sensitising agents or exogenous insulin results in marked recovery of insulin secretory capacity $[4,5]$. These observations are suggestive of a cascade whereby metabolic stress against a background of susceptible beta cells results in early glucose intolerance, which in turn worsens insulin secretory function and causes more dysmetabolism, more acquired beta cell defects and so on. The cause of the initial hyperglycaemia and what comprises the biochemical nature of beta cell dysfunction in type 2 diabetes remain unknown. Of note, beta cell mass is lowered by $40 \%$ in obese patients with prediabetes and by $60 \%$ in those with type 2 diabetes [6].

Our laboratory has proposed that a lowered beta cell mass allows hyperglycaemia to result from metabolic stresses that otherwise would have no impact on glucose tolerance [7]. Experimental reduction of beta cell mass in rodents and dogs by partial pancreatectomy (Px) severe enough to cause hyperglycaemia results in defective glucose-stimulated insulin secretion (GSIS) and peripheral insulin resistance [8-10]. In animals with less radical reduction in beta cell mass, an additional metabolic insult such as high sucrose diet [7] or corticosteroids [11] is necessary to cause hyperglycaemia. However, these are non-physiological metabolic stressors. It is unknown whether obesity-related insulin resistance and hyperlipidaemia, in the context of reduced beta cell mass, are sufficient to initiate hyperglycaemia that otherwise would be clinically silent.

Studies in humans and animals have suggested the concept of hyperglycaemia-induced depletion of the releasable stores of insulin (also called beta cell exhaustion) based on augmented insulin responses following inhibition of insulin secretion by diazoxide or somatostatin [12-14]. On the other hand, in vitro and whole-animal studies have reported a direct inhibitory effect of excess NEFA, such as occurs with insulin resistance, on glucose-mediated insulin secretion [15], proinsulin biosynthesis [15, 16] and beta cell survival $[17,18]$. Also in vitro studies have shown a synergistic toxic effect of high glucose and saturated NEFA, a process termed glucolipotoxicity, leading to beta cell dysfunction and death $[19,20]$. However, most of the in vivo data were obtained in animals such as the Zucker diabetic fatty rat (ZDF) [21], the $d b / d b$ mouse [22] or the gerbil Psammomys obesus [23], which are obese and hyperlipidaemic, and have extreme hyperglycaemia. Very high glycaemia alone can negatively impact on these processes in the absence of hyperlipidaemia [24, 25], so there is a need to better understand the biochemical basis of beta cell failure in milder models of type 2 diabetes.

In this study, we determined the effects of a $60 \%$ Px in obese normoglycaemic, insulin-resistant, hyperlipidaemic Zucker fatty (ZF) rats [26]. We have previously shown that this degree of Px had no impact on glycaemia in non-obese Sprague-Dawley rats [27]. ZF rats are normally able to fully compensate for insulin resistance through large enhancements in beta cell mass [28] and function [26, 29]. The latter involves increased glucose utilisation and oxidation along with elevated anaplerosis and pyruvate cycling pathways [26]. We recently reported that GSIS is markedly augmented by NEFA in ZF rat islets [29] and that this coincides with enhanced glycerolipid/fatty acid (GL/ FA) cycling [29].

We used this new animal model of mild type 2 diabetes to determine whether a progressive fall in beta cell mass and/or function contribute to beta cell failure in obesityand hyperlipidaemia-associated early type 2 diabetes.

\section{Methods}

Animals Zucker lean (ZL) $(f a /+$ or $+/+)$ and ZF (falfa) male rats were purchased from Harlan (Indianapolis, IN, USA) and Charles River (St Constant, QC, Canada). At 6 weeks of age rats underwent a $60 \% \mathrm{Px}$ under aseptic conditions as previously described [7]. Control rats (Sham) underwent laparotomy and gentle handling of the pancreas. Rats had free access to standard laboratory chow and tap water. Rats were individually housed in a temperature- and humiditycontrolled facility on a $12 \mathrm{~h}$ light/dark cycle. Blood variables were studied at 1,2 and 3 weeks post-surgery. Islet beta cell mass, beta cell proliferation and all isolated islet studies were performed 3 weeks post-surgery. All protocols were approved by the Institutional Animal Use and Care Committees.

Blood/plasma variables These were determined as detailed in the Electronic Supplementary Material (ESM). 
Pancreas beta cell mass, proliferation, apoptosis and analysis of beta cell clusters and small islets See ESM.

In situ perfused pancreas and pancreas insulin content See ESM.

Islet isolation and culture, islet proinsulin biosynthesis, islet triacylglycerol and protein contents and islet mRNA analysis See ESM including ESM Table 1 for listing of primers used.

Islet glucose metabolism, lipolysis and insulin secretion See ESM.

Islet fatty acid oxidation and esterification These were determined as in [29] and as detailed in the ESM.

Statistical analysis All results are expressed as mean \pm SEM. Each data-point is derived from an individual rat. The ZL and ZF rat data were analysed separately. Statistical differences were calculated by two-way ANOVA with Bonferroni post hoc testing or by unpaired Student's $t$ test. A $p$ value of $<0.05$ was considered statistically significant. Prism version 4 (GraphPad Software, San Diego, CA, USA) was used to perform the analyses.

\section{Results}

Body weight and plasma variables At 3 weeks postsurgery, body weight was not different between ZL-Sham and ZL-Px rats $(263 \pm 3$ vs $264 \pm 2$ g, $n=39$ and 43 , respectively) or between ZF-Sham and ZF-Px rats $(366 \pm 6$ vs $354 \pm 6 \mathrm{~g}, n=34$ and 44 , respectively). The $60 \% \mathrm{Px}$ had minimal effects on non-fasting glycaemia (no greater than $1.0 \mathrm{mmol} / \mathrm{l}$ at any time point), insulinaemia and lipidaemia in ZL rats, but caused progressively worsening hyperglycaemia in ZF rats (Fig. 1a, c, e, g). Plasma glucose in ZF-Px rats increased from $6.5 \pm 0.2 \mathrm{mmol} / 1$ on the day of surgery to $14.8 \pm 1.3 \mathrm{mmol} / \mathrm{l}$ at 3 weeks post-surgery (Fig. 1b). ZF-Px rats were unable to maintain the equivalent levels of compensatory hyperinsulinaemia to obesityinduced insulin resistance as was observed in the ZF-Sham rats (Fig. 1d). Plasma triacylglycerol levels progressively rose over the 3 weeks post-surgery in ZF-Px compared with ZF-Sham rats (Fig. 1h). Plasma NEFA levels, however, were not altered by Px in any of the groups (Fig. 1e, f). Neither glucagon-like peptide-1 (GLP-1) nor glucosedependent insulinotropic polypeptide (GIP) plasma levels were altered by Px surgery in ZL rats. GIP levels in ZF rats were twice those of $Z \mathrm{~L}$ rats $(p<0.001)$ and were unaffected by the $60 \%$ Px. GLP-1 levels in ZF-Sham rats were equal to
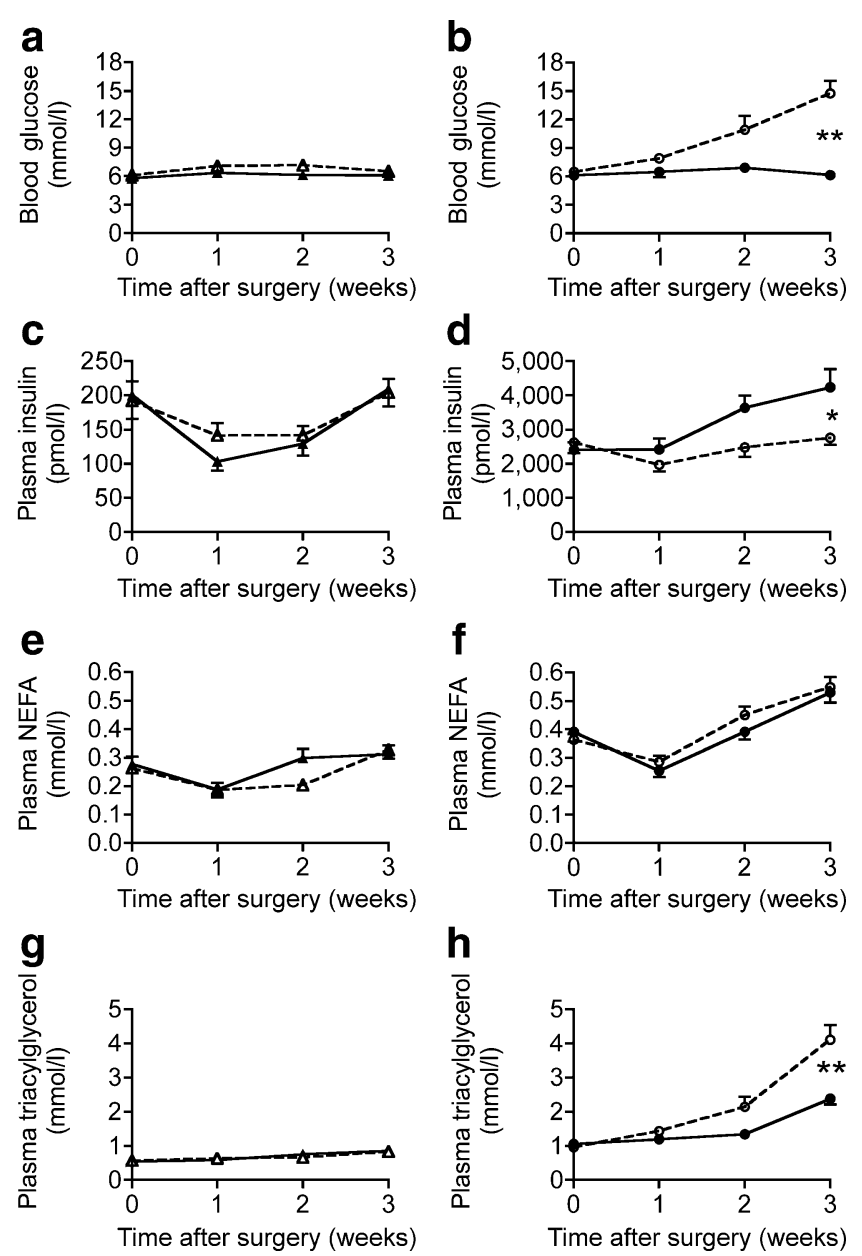

Fig. 1 a, b Blood glucose, c, d plasma insulin, e, f plasma NEFA and $\mathbf{g}, \mathbf{h}$ plasma triacylglycerol (TG) levels were determined weekly in the fed state (09:00-10:00 hours) in ZL Sham (continuous lines, black triangles) and ZL-Px (dashed lines, white triangles) rats (a, c, e, g) and in ZF Sham (continuous lines, black circles) and ZF-Px (dashed lines, white circles) rats $(\mathbf{b}, \mathbf{d}, \mathbf{f}, \mathbf{h})$. Values are means \pm SEM of 7-23 rats per group. $p<0.0001$ for Px effect (b); $p<0.01$ for Px effect (d); $p<0.005$ for Px effect (h), two-way ANOVA; ${ }^{*} p<0.01$ vs Sham, ${ }^{* *} p<0.001$ vs Sham (Bonferroni post hoc test)

those in ZL rats, but unlike GIP, they doubled in the ZF-Px vs ZF-Sham rats ( $p<0.03$; ESM Table 2$)$.

Beta cell mass, proliferation and islet morphology At 3 weeks post-surgery, beta cell mass in ZL-Px rats was only $40 \%$ reduced compared with that of ZL-Sham rats ( $p=$ 0.09), showing a modest degree of regeneration (Fig. 2a). Beta cell mass of ZF-Px rats had recovered to nearly $80 \%$ of the ZF-Sham group ( $p=0.26$; Fig. $2 \mathrm{~b}$ ). At 3 weeks postsurgery this occurred with no observed rise in beta cell proliferation in the Px groups (Fig. 2i, j). Immunohistochemical examination of pancreas sections from ZL-Sham and ZL-Px rats 3 weeks post-surgery showed islets of normal appearance with discrete boundaries (Fig. 3a, c). Single-cell and small clusters of beta cells were occasion- 
a

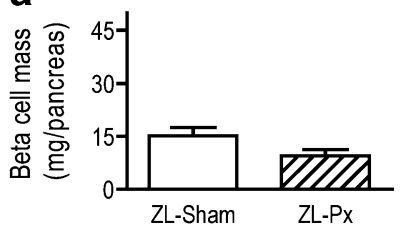

C

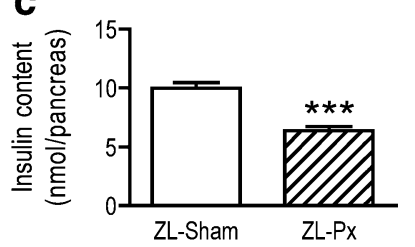

e
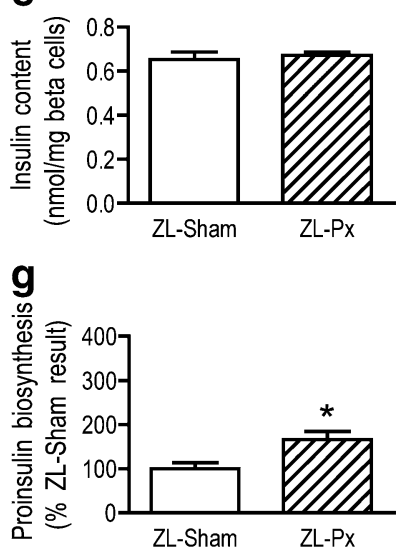

i

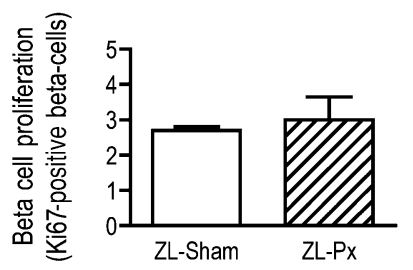

b

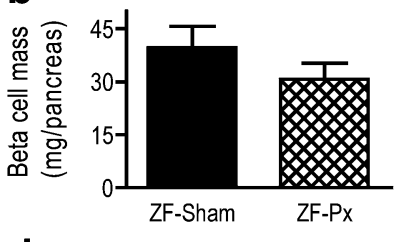

d

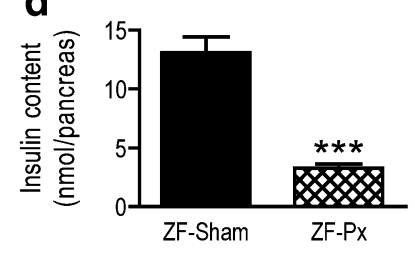

f

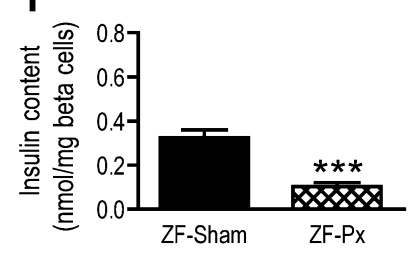

h

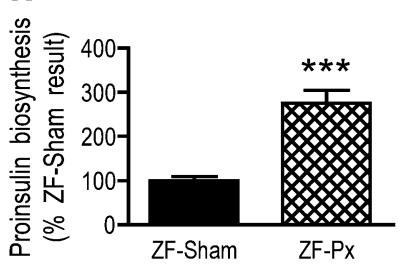

j

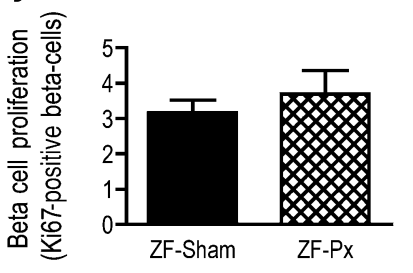

Fig. 2 a, b Pancreas beta cell mass, c, $\mathbf{d}$ insulin content per pancreas, $\mathbf{e}, \mathbf{f}$ insulin content per beta cell mass, $\mathbf{g}, \mathbf{h}$ proinsulin biosynthesis and $\mathbf{i}, \mathbf{j}$ beta cell proliferation in freshly isolated islets from ZL Sham (white bars) and ZL-Px (hatched bars) (a, c, e, g, i), and ZF Sham (black bars) and ZF-Px (cross-hatched bars) rats (b, d, f, h, j). All variables measured at 3 weeks post-surgery. Data are expressed as mean \pm SEM of four to five rats per group (beta cell mass, proliferation and insulin content) and three experiments per group (proinsulin biosynthesis). ${ }^{*} p<0.05, * * * p<0.001$ vs Sham (unpaired two-tailed Student's $t$ test)

ally found in both ZL groups (Fig. 3a, c). ZF-Sham rats were characterised by discrete but larger islets than $\mathrm{ZL}$ rats, with a greater heterogeneity of insulin staining (Fig. 3b). There were also small islet clusters associated with ducts and within acinar tissue, which, upon morphometric analysis, were more frequent than in the ZL groups (ESM Fig. 1). In the ZF-Px rats, large, irregularly shaped insulindepleted islets were noted (Fig. 3d), along with an increase in acinar- and duct-associated single beta cells and beta cell

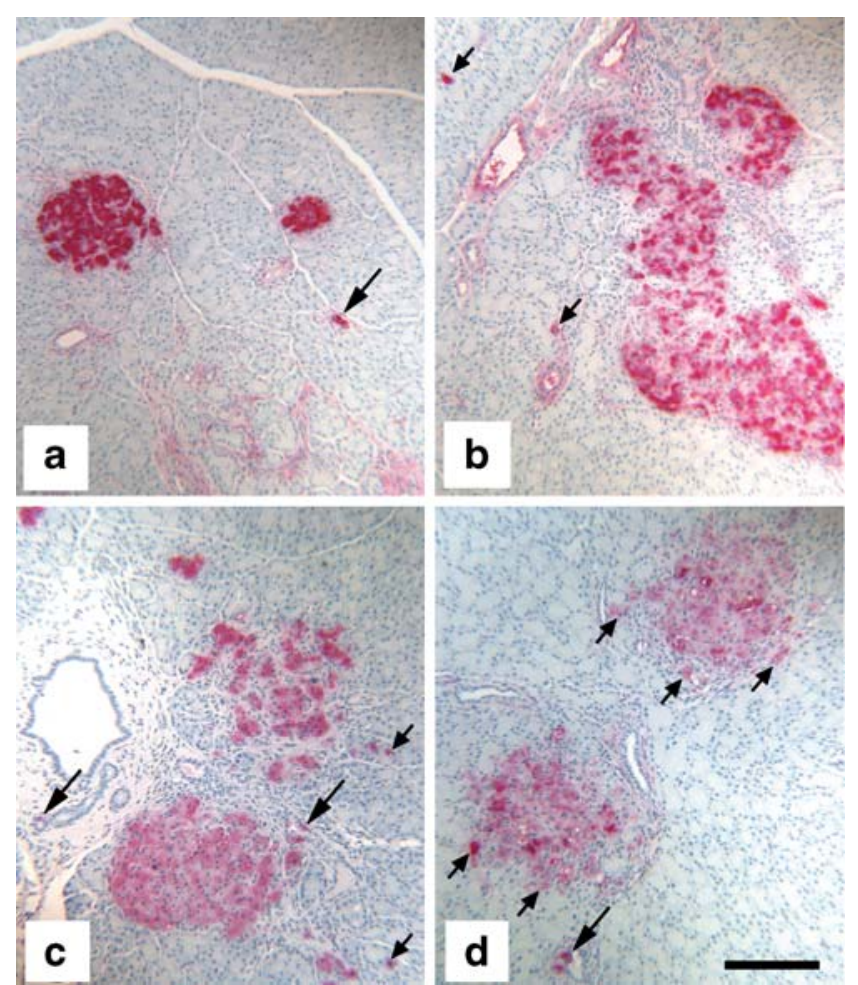

Fig. 3 Representative pancreas fields from Sham and 60\% Px ZL and $\mathrm{ZF}$ rats at 3 weeks post-surgery. Sections were immunostained for insulin (red); long arrows, single-cell and small clusters of beta cells associated with ducts; short arrows, beta cell clusters associated with acini or very small ducts. a ZL-Sham and $\mathbf{c}$ ZL-Px rats exhibited beta cell clusters (long arrows). ZF-Sham rats (b) showed increased islet size compared with ZL. d ZF-Px rats showed insulin-depleted beta cells and markedly greater prevalence of acini-associated beta cells (short arrows) in the vicinity of large islets. Scale bar, $100 \mu \mathrm{m}$

clusters compared with the ZL rats. In nearly all of the beta cell cluster/islet size classes, ZF-Sham and ZF-Px rats exhibited increased islet numbers compared with the $\mathrm{ZL}$ groups (ESM Fig. 1). TUNEL positive beta cells were extremely rare in all groups. Apoptosis events were therefore too low to be measured.

Pancreas insulin content and proinsulin biosynthesis The measured pancreas insulin content (Fig. 2c, d) was consistent with the insulin staining intensity from Fig. 3. The result in the ZL-Px rats was $64 \%$ of the ZL-Sham rats in absolute terms, but the values were identical when expressed per milligram of beta cell mass (Fig. 2c, e). In contrast, insulin content per mg beta cell mass was $70 \%$ lower in ZF-Px than in ZF-Sham rats (Fig. 2f). Proinsulin biosynthesis was measured using $\left[{ }^{35} \mathrm{~S}\right]$ methionine incorporation at $7.8 \mathrm{mmol} / \mathrm{l}$ glucose in freshly isolated islets. There was a modest increase in ZL-Px vs ZL-Sham islets (Fig. 2g). However, proinsulin biosynthesis dramatically increased by threefold in ZF-Px vs ZF-Sham islets (Fig. 2h). 


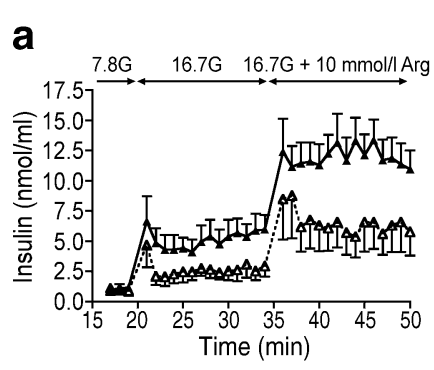

b

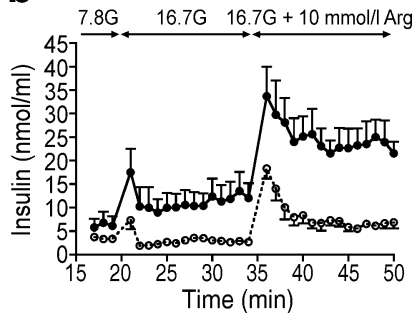

C

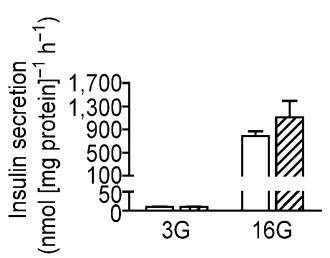

d

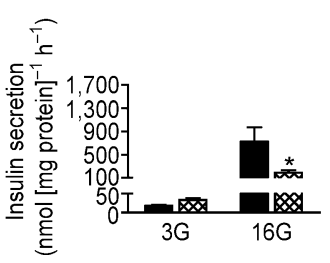

Fig. 4 Reduced glucose-stimulated insulin secretion in perfused pancreas and isolated islets of ZF-Px rats at 3 weeks post-surgery. a Insulin secretion assessed by in situ pancreas perfusion in ZL-Sham (continuous lines, black triangles; $n=5$ ) and ZL-Px (dashed lines, white triangles; $n=4$ ) rats, and $\mathbf{b}$ in ZF-Sham (continuous lines, black circles; $n=5$ ) and ZF-Px (dashed lines, white circles; $n=5$ ) rats. The three-step perfusion protocol using $7.8(7.8 \mathrm{G})$ and $16.7(16.7 \mathrm{G}) \mathrm{mmol} / \mathrm{l}$ glucose and $16.7 \mathrm{mmol} / \mathrm{l}$ glucose with $10 \mathrm{mmol} / \mathrm{l}$ arginine $(16.7 \mathrm{G}+10 \mathrm{mmol} / \mathrm{l}$ $\mathrm{Arg}$ ) is shown at the top (a, b). Data are expressed as mean \pm SEM of four to five rats for each group. c Insulin secretion assessed in isolated islets from ZL-Sham (white bars) and ZL-Px (hatched bars) rats, and d in ZF-Sham (black bars) and ZF-Px (cross-hatched bars) rats. Insulin secretion was measured as rate of insulin release into incubation medium over $3 \mathrm{~h}$ at $3(3 \mathrm{G})$ and $16(16 \mathrm{G}) \mathrm{mmol} / \mathrm{l}$ glucose from batches of 60 freshly isolated islets. Means \pm SEM of four to eight rats per group. $p<0.05$ for Px effect (two-way ANOVA) (d); ${ }^{*} p<0.05$ vs Sham $16 \mathrm{G}$ (Bonferroni post hoc test)
Insulin secretion studies In in situ pancreas perfusion experiments, ZL-Sham rats exhibited biphasic insulin response to high glucose and a doubling of insulin output with arginine (Fig. 4a). The same pattern of insulin secretion was observed in ZL-Px rats. Also, the increases in insulin secretion resulting from 7.8 to $16.7 \mathrm{mmol} / 1$ glucose and with arginine were equal to ZL-Sham rats after adjusting for the reduced pancreatic beta cell mass (Table 1). Identical results were observed in ZF-Sham rats, i.e. larger insulin responses in absolute terms (Fig. 4b) that were similar to both groups of ZL rats when adjusted for their larger beta cell mass (Table 1). In ZF-Px rats by contrast, the change from 7.8 to $16.7 \mathrm{mmol} / \mathrm{l}$ glucose failed to elicit an increase in insulin secretion, except for a small first phase. The ZF-Px rats, however, had a clear insulin response to arginine, with proportionately smaller, but apparently normal first and later phase secretion compared with the ZF-Sham rats (Fig. 4b).

When expressed per insulin content, no differences in the incremental increases of insulin secretion between 7.8 and $16.7 \mathrm{mmol} / \mathrm{l}$ glucose or after addition of arginine were observed in ZL-Sham, ZL-Px and ZF-Sham rats (Table 1). However, in ZF-Px rats, the lack of an insulin response to $16.7 \mathrm{mmol} / \mathrm{l}$ glucose persisted, while the insulin response to arginine equalled or exceeded that of other groups (Table 1).

Consistent with the pancreas perfusion results, GSIS corrected for islet protein content was not altered in freshly isolated islets 3 weeks post-Px in ZL rats (Fig. 4c). GSIS from islets of ZF-Px rats was impaired (74\% lower) at $16 \mathrm{mmol} / \mathrm{l}$ glucose compared with ZF-Sham islets (Fig. 4d).

Table 1 Step-ups in insulin secretion upon increase of glucose from 7.8 to $16.7 \mathrm{mmol} / \mathrm{l}$ glucose, plus addition of $10 \mathrm{mmol} / 1 \mathrm{arginine}$ as indicated Measurement mode and variable Step-up in insulin secretion per animal group

ZL-Sham $(n=5) \quad$ ZL-Px $(n=4) \quad$ ZF-Sham $(n=5) \quad$ ZF-Px $(n=5)$

Insulin per beta cell mass (pmol/mg beta cells)

\begin{tabular}{lcccc}
$16.7 \mathrm{mmol} / 1$ glucose & $0.27 \pm 0.07$ & $0.17 \pm 0.07$ & $0.14 \pm 0.03$ & $-0.02 \pm 0.00^{\mathrm{b}, \mathrm{c}}$ \\
$16.7 \mathrm{mmol} / 1$ glucose $+10 \mathrm{mmol} / 1$ arginine & $0.40 \pm 0.07$ & $0.38 \pm 0.15$ & $0.33 \pm 0.05$ & $0.19 \pm 0.03^{\mathrm{a}, \mathrm{c}}$ \\
lin per total pancreas insulin content (pmol/nmol insulin) & & & \\
$16.7 \mathrm{mmol} / 1$ glucose & $0.4 \pm 0.1$ & $0.3 \pm 0.1$ & $0.4 \pm 0.1$ & $-0.1 \pm 0.1^{\mathrm{b}, \mathrm{c}}$ \\
$16.7 \mathrm{mmol} / 1$ glucose $+10 \mathrm{mmol} / 1$ arginine & $0.6 \pm 0.1$ & $0.6 \pm 0.2$ & $1.0 \pm 0.2$ & $1.8 \pm 0.4^{\mathrm{a}}$ \\
\hline
\end{tabular}

ZF and ZL rats at 3 weeks post-Px or sham surgery underwent in situ pancreas perfusion using the protocol shown in Fig. 4a, b. Each animal's step-up in insulin secretion in response to the increase from 7.8 to $16.7 \mathrm{mmol} / \mathrm{l}$ glucose was calculated as the mean concentration of the samples collected at $16.7 \mathrm{mmol} / \mathrm{l}$ glucose minus the mean of the three samples collected at $7.8 \mathrm{mmol} / \mathrm{l}$ glucose. The step-up in response to addition of $10 \mathrm{mmol} / \mathrm{l}$ arginine was calculated as the mean insulin concentration of the samples at $16.7 \mathrm{mmol} / 1$ glucose $+10 \mathrm{mmol} / 1$ arginine minus the insulin value of the last sample collected at $16.7 \mathrm{mmol} / 1$ glucose. Those data were divided by each animal's pancreas insulin content to calculate insulin secretion per nmol of pancreas insulin content, and by the mean 3-week post-surgery beta cell mass measures from Fig. 2 for insulin secretion per $\mathrm{mg}$ of beta cell mass.

Results are mean \pm SEM; statistical significance was determined by analysis of variance (ANOVA)

${ }^{\mathrm{a}} p<0.05$ vs ZL-Sham; ${ }^{\mathrm{b}} p<0.01$ vs ZL-Sham; ${ }^{\mathrm{c}} p<0.05$ vs ZF-Sham 
Islet metabolism studies Islets from ZL-Px rats showed enhanced glucose utilisation and oxidation that was most evident at high glucose $(27.7 \mathrm{mmol} / \mathrm{l})$ levels (Fig. 5a, c). By contrast, glucose utilisation and oxidation values were similar in islets from ZF-Sham and ZF-Px rats (Fig. 5b, d).

The rate of glycerol release, an index of lipolysis, was higher at 16 than at $3 \mathrm{mmol} / \mathrm{l}$ glucose in all groups (Fig. 5e, f). The $60 \%$ Px in both ZL and ZF rats resulted in enhanced islet lipolysis rates, which was most evident at the higher glucose level in ZF rats (Fig. 5f).

The incorporation of palmitate into neutral lipids was assessed during a $16 \mathrm{~h}$ radiolabelling period (equilibrium phase). The $60 \%$ Px did not alter net palmitate esterification into monoacylglycerol, diacylglycerol or triacylglycerol (at 3 or $16 \mathrm{mmol} / 1$ glucose) in islets from ZL rats (Fig. 6a, c,
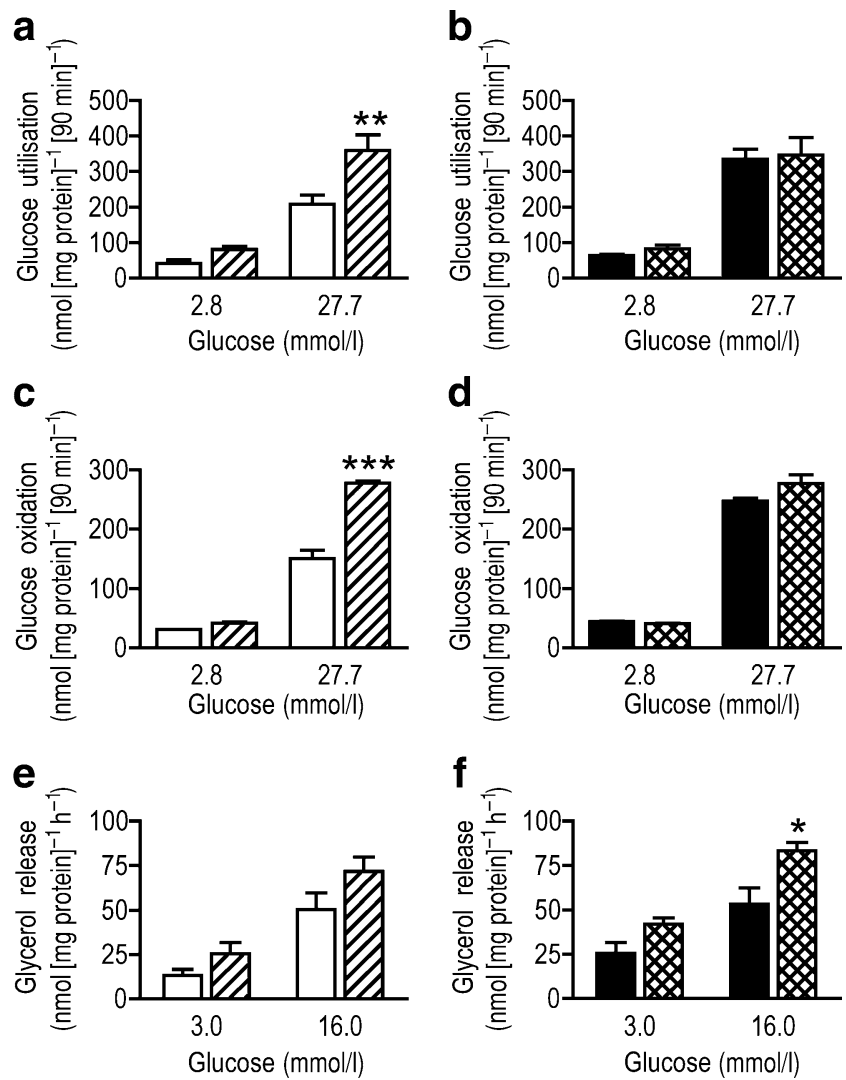

Fig. 5 Lack of compensatory rise in glucose metabolism in islets of $60 \%$ Px ZF rats, but enhanced lipolysis in ZL-Px and ZF-Px islets. a, b Glucose utilisation, c, d glucose oxidation and e, f lipolysis were measured as the production of ${ }^{3} \mathrm{H}_{2} \mathrm{O},{ }^{14} \mathrm{CO}_{2}$ and glycerol respectively in isolated islets from ZL-Sham (white bars) and ZL-Px (hatched bars) rats (a, c, e), and in ZF-Sham (black bars) and ZF-Px (cross-hatched bars) rats $(\mathbf{b}, \mathbf{d}, \mathbf{f})$. $\mathbf{a}-\mathbf{d}$ Batches of 20 islets in triplicate from each rat were incubated at 2.8 and $27.7 \mathrm{mmol} / 1$ glucose for $90 \mathrm{~min}$. Means $\pm \mathrm{SEM}$ of three rats per group. e, $\mathbf{f}$ Batches of 60 freshly isolated islets per rat were incubated at 3.0 and $16.0 \mathrm{mmol} / 1$ glucose for $3 \mathrm{~h}$. Means $\pm \mathrm{SEM}$ of four to eight rats per group. $p<0.01$ for Px effect (a, c, f); $p<0.05$ for Px effect (e) (two-way ANOVA); ${ }^{*} p<0.05, * * p<0.01, * * * p<0.001$ vs Sham for same glucose concentration (Bonferroni post hoc test)
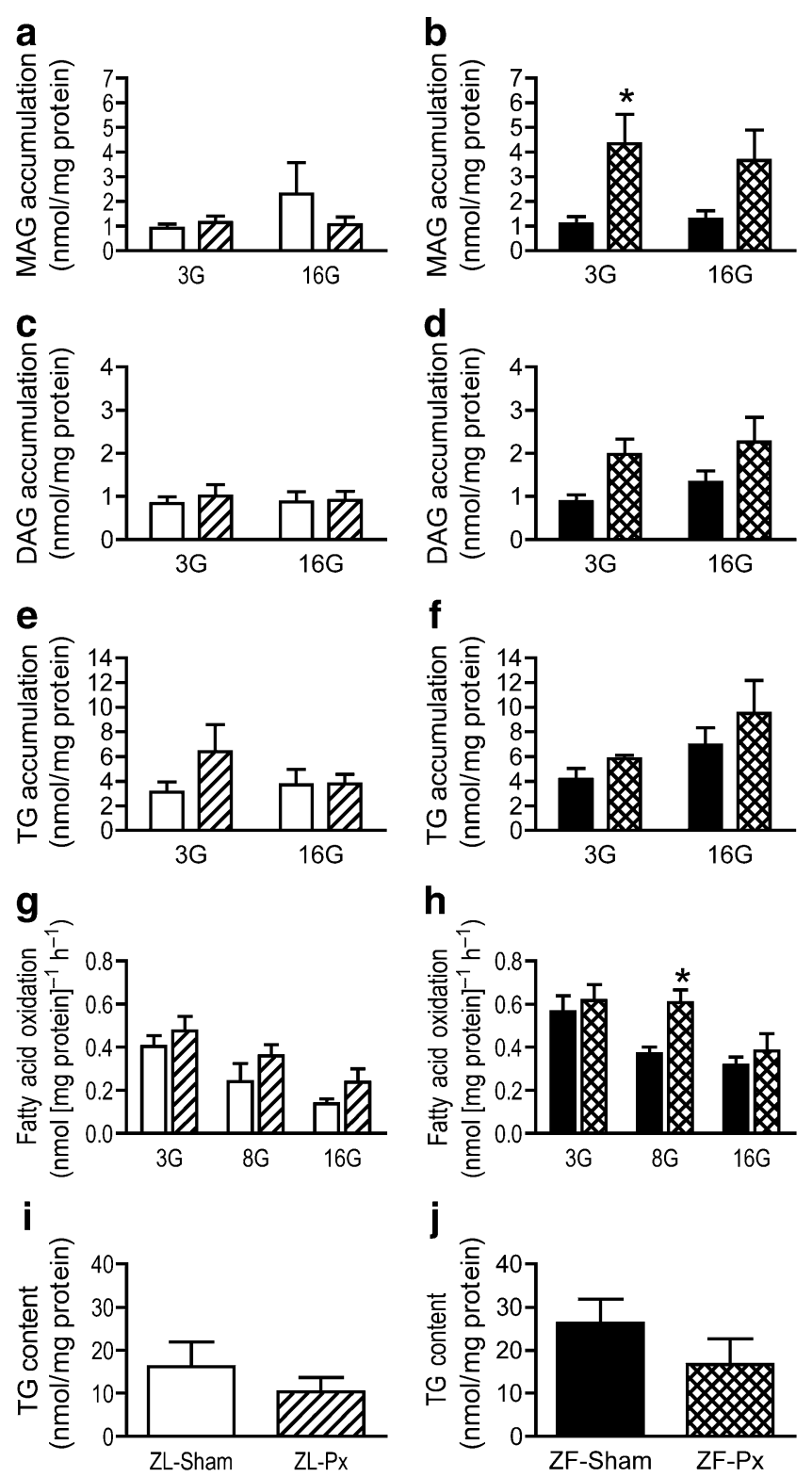

Fig. 6 Lipid partitioning is altered in islets of $60 \% \mathrm{Px} \mathrm{ZF}$ rats without the development of steatosis. Fatty acid esterification into a, b monoacylglycerol (MAG), c, d diacylglycerol (DAG) and e, f triacylglycerol (TG). Islets were isolated from ZL-Sham (white bars) and ZL-Px (hatched bars) rats (a, c, e, g, i), and ZF-Sham (black bars) and ZF-Px (cross-hatched bars) rats $(\mathbf{b}, \mathbf{d}, \mathbf{f}, \mathbf{h}, \mathbf{j})$. Batches $(\mathbf{a}-\mathbf{f})$ of 50 islets from each rat were incubated for $16 \mathrm{~h}$ at $3(3 \mathrm{G})$ or $16(16 \mathrm{G})$ $\mathrm{mmol} / \mathrm{l}$ glucose in the presence of $0.1 \mathrm{mmol} / 1$ palmitate and $\left[1-{ }^{14} \mathrm{C}\right]$ palmitate. Means \pm SEM of four to nine rats per group. $\mathbf{g}, \mathbf{h}$ Fatty acid oxidation. Batches of 50 islets were pre-labelled with palmitate tracer for $16 \mathrm{~h}$ and then incubated for a further $2 \mathrm{~h}$ at $3(3 \mathrm{G}), 8(8 \mathrm{G})$ and 16 (16G) $\mathrm{mmol} / \mathrm{l}$ glucose in the presence of $0.1 \mathrm{mmol} / 1$ palmitate, $[9,10$ (n) $\left.-{ }^{3} \mathrm{H}\right]$ palmitate and $1.0 \mathrm{mmol} / 1$ carnitine. Means $\pm \mathrm{SEM}$ of four to five rats per group in two separate experiments. $\mathbf{i}$, $\mathbf{j}$ Total islet TG content was measured in separate batches of 100 fresh islets. Means \pm SEM of five to seven rats per group. $p<0.05$ for Px effect (d, h); $p<0.01$ for Px effect (b), (two-way ANOVA); ${ }^{*} p<0.05$ vs Sham for same glucose concentration (Bonferroni post hoc test) 
Fig. 7 Islets of ZF-Px rats display changes in mRNA levels of genes involved in lipid partitioning and markers of the phenotype of differentiated beta cells. Gene expression was assessed using realtime RT-PCR, and genes grouped according to function. a, b Fatty acid synthesis and esterification. c, d Fatty acid oxidation. e, f Lipolysis. g, h Transcription factors. $\mathbf{i}, \mathbf{j}$ Receptors for incretin hormones and fatty acids. k, I Glycolysis, anaplerosis and insulin genes. Islets were isolated from ZL-Sham (white bars) and ZL-Px (hatched bars) rats (a, c, e, g, i, k), and from ZF-Sham (black bars) and ZF-Px (cross-hatched bars) rats $(\mathbf{b}, \mathbf{d}, \mathbf{f}, \mathbf{h}, \mathbf{j}, \mathbf{l})$. Results are expressed as fold change over corresponding Sham animals and have been normalised to cyclophilin A. Means \pm SEM of four to eleven rats. ${ }^{*} p<0.05,{ }^{* *} p<0.01, * * * p<0.001$ compared with Sham rats (unpaired two-tailed Student's $t$ test)

e). The incorporation of palmitate into mono- and diacylglycerol, however, was enhanced in islets of ZF-Px compared with ZF-Sham islets (Fig. 6b, d), this being most marked for monoacylglycerol at $3 \mathrm{mmol} / \mathrm{l}$ glucose. Net palmitate esterification into triacylglycerol was no higher in ZF-Px than in ZF-Sham islets (Fig. 6f).

Glucose reduced palmitate oxidation in both ZL and ZF rats (Fig. $6 \mathrm{~g}, \mathrm{~h}$ ). There was a trend for palmitate oxidation to be increased in ZL-Px compared with ZL-Sham islets, but this was not statistically significant (Fig. 6g). Palmitate oxidation, however, was significantly enhanced in ZF-Px compared with ZF-Sham islets, a finding that was most apparent at $8 \mathrm{mmol} / \mathrm{l}$ glucose (Fig. $6 \mathrm{~h}$ ).

The Px surgery had no significant effect on triacylglycerol content in islets of either the ZL or ZF rats (Fig. 6i, j).

Gene expression studies The mRNA expression of key enzymes and transcription factors related to glucose and lipid metabolism, anaplerosis and incretin signalling in freshly isolated islets was determined by real-time RT-PCR (Fig. 7). Of all the genes assessed, only the mRNA levels of Pparg (also known as Ppary) and Ppara (also known as Ppar $\alpha$ ) were altered in response to $60 \%$ Px compared with Sham surgery in ZL rats. Pparg was increased 2.5-fold, whereas Ppara was reduced by $34 \%$ (Fig. 7a, c) in islets of ZL-Px compared with ZL-Sham rats. Of note, very similar changes to the mRNA expression of Pparg and Ppara were observed in response to Px in islets of ZF rats (Fig. 7b, d). These results would be in keeping with the notion that alterations in these metabolic transcription factors are involved in normal compensation to beta cell mass reduction.

Some additional changes, not observed in islets of $\mathrm{ZL}$ rats, occurred in islet gene expression at the mRNA level of ZF-Px compared with ZF-Sham rats and are therefore more likely to be related to decompensation processes in islet beta cells of the ZF-Px rats. They included: (1) a 4.5-fold increase in $S c d 1$ (encoding an enzyme involved in desaturation of the fatty acids important in glycerolipid metabolism [30]); (2) a 29\% decrease in Adpn (encoding a
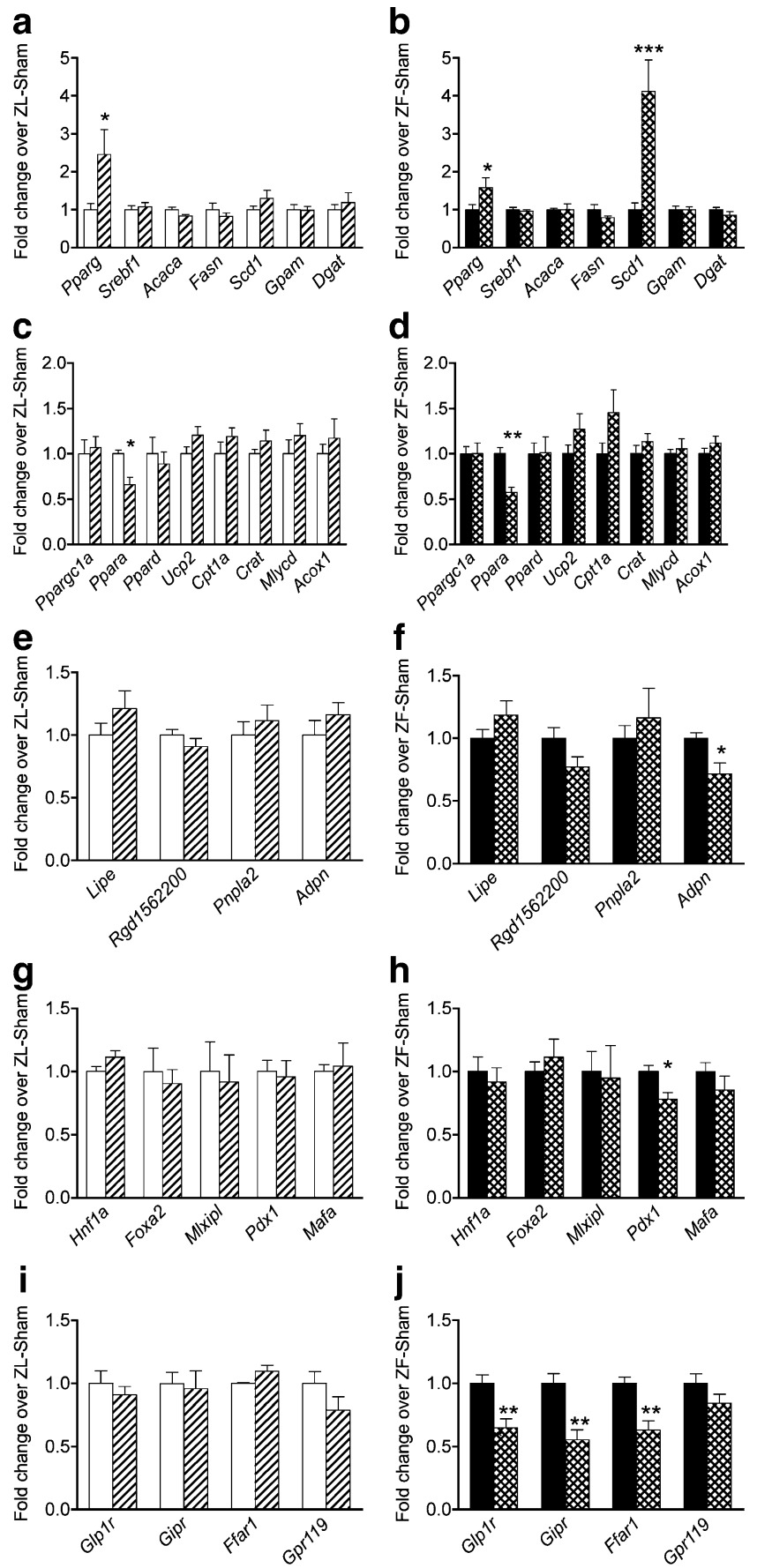

h
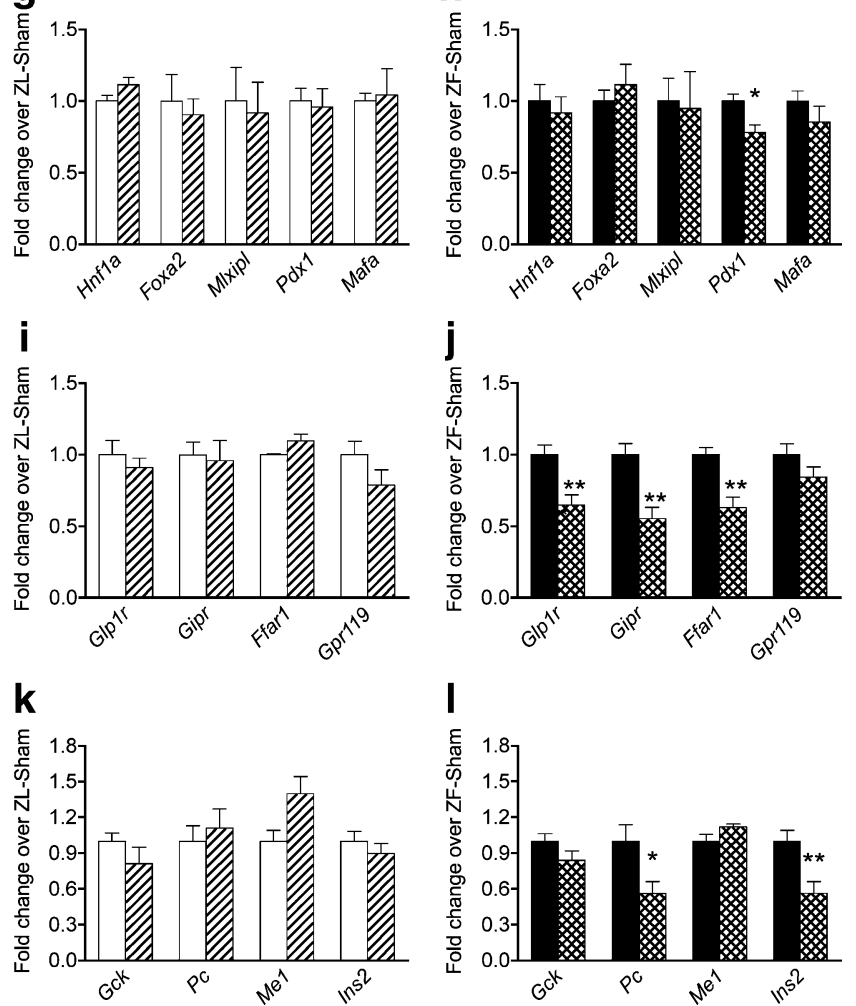
low-activity lipase enzyme that is implicated in energy balance [31]); (3) a 22\% decrease in $P d x 1$ (a key islet beta cell differentiation factor); (4) $35 \%$ and $45 \%$ decreases in the incretin receptors of GLP-1 (Glplr) and GIP (Gipr) respectively; (5) a 37\% decrease in Ffarl (also known as Gpr40; encodes a receptor for NEFA); (6) a $34 \%$ decrease in the key beta cell anaplerosis gene $P c$ (a similar decrease was observed at the protein level of pyruvate carboxylase; not shown); and (7) a 34\% decrease in the Ins2 (insulin) gene (Fig. 7).

\section{Discussion}

One of the two principal questions of this study was whether a $60 \%$ Px in the context of obesity and hyperlipidaemia would result in further compensation or beta cell failure? ZF-Px rats overall compensated for the reduction of beta cell mass for approximately 1 week post-surgery. However, hyperglycaemia worsened to a level of $14 \mathrm{mmol} / \mathrm{l}$ after 3 weeks. These findings confirm the view that a lowering of beta cell mass induces susceptibility of islet beta cells to be overwhelmed with insulin resistance and hyperlipidaemia, resulting in hyperglycaemia.

The second question relates to the molecular basis of glucolipotoxicity in vivo in an animal model of moderate type 2 diabetes associated with hyperlipidaemia. We wished to determine if the prototype in vitro features of beta cell glucolipotoxicity in the form of falling beta cell mass secondary to enhanced apoptosis and excess storage of triacylglycerol would occur $[3,21]$. In fact, we found the opposite, as beta cell mass was not further reduced but almost restored to normal at 3 weeks post-surgery. We also observed no increase in islet triacylglycerol in the diabetic ZF-Px rats. We conclude that the main beta cell features of ZF-Px rats, which represent a model that is more closely related to human type 2 diabetes than models with rapid onset of extreme hyperglycaemia, is beta cell exhaustion as reflected in impaired GSIS and a lowered pancreas insulin content, and not a reduction of beta cell mass or islet steatosis.

What is the functional importance of the reduced insulin stores in ZF-Px rats $(85 \%$ lowered when adjusted for beta cell mass)? We and others have suggested that a depletion of beta cell insulin stores is a cause of the lowered insulin secretion in type 2 diabetes, these proposals being based on studies of animal models of diabetes and of human patients showing a paradoxical rise in stimulated insulin output after pharmacological [12-14] and fasting-induced inhibition of insulin secretion $[32,33]$. The current study supports this view in part, as the lowered insulin response to arginine at high glucose in the ZF-Px rats equalled or exceeded that in other groups after correcting for their relative pancreas insulin contents. In contrast, the near-total loss of GSIS implies another intrinsic regulatory defect in beta cell glucose metabolism and/or signalling, and may account for the well-known selectivity of the insulin secretion defect for glucose vs non-glucose secretagogues in type 2 diabetes [3].

The results provide insight into the mechanism of the fall in pancreas insulin content in the ZF-Px rats. A lowered proinsulin mRNA level is a common feature observed in beta cell studies with combination of high glucose and excess NEFA [16]; here, in fact, proinsulin mRNA levels were $50 \%$ reduced in the ZF-Px islets. However, this is often assumed to imply a reduced rate of proinsulin production. Yet measured proinsulin synthesis was threefold increased in the ZF-Px islets. This is not too surprising, as a rise in proinsulin synthesis is an expected response to hyperglycaemia [34] and translational control is a glucosedriven regulatory mechanism [35]. Nonetheless, the reduced level of the proinsulin transcript is likely to have restrained the compensatory increase in biosynthesis, thus contributing to the failed maintenance of insulin stores. Finally, another potential mechanism for the lowered insulin content, and one that needs additional investigation, relates to intracellular insulin granule degradation [36]. In support of this possibility, a 12-fold increase in degradation vacuoles in beta cells of Rab3a $a^{-/}$mice, which are glucoseintolerant because of impaired insulin secretion, has been shown [37]. In addition, high-fat diet has recently been shown to stimulate beta cell autophagy [38].

What was the mechanism of the almost complete recovery of beta cell mass in the ZF-Px rats by 3 weeks? Proliferation of islet cells was minimally and not significantly increased. This does not rule out some increased beta cell proliferation prior to the 3 week analysis. TUNEL staining failed to discern differences in beta cell apoptosis between the groups, possibly due to efficient islet scavenging mechanisms. Especially noteworthy was the fact that, in Sham and Px ZF rats, as in our previous report of unmanipulated ZF rats [28], the prevalence of beta cell clusters was high, suggesting a dominant role for beta cell neogenesis in beta cell mass regeneration.

What is the biochemical basis of the severe beta cell dysfunction and selective decrease in GSIS in this animal model? Previously, we have shown enhanced glucose utilisation and oxidation in islets of ZF rats that fully compensate for insulin resistance [26]. Here we show similar increases in glucose utilisation and oxidation in islets of ZL-Px rats that successfully compensate for beta cell mass reduction. Thus, enhanced islet beta cell glucose utilisation and oxidation are likely to be involved in beta cell compensation processes in many situations. In the failing ZF-Px rat islets, glucose metabolism was maintained at the same level as that observed in compensating $\mathrm{ZF}$ 
islets. This is possibly due to an already maximally compensated islet glucose metabolism in the obese hyperinsulinaemic ZF animal and is consistent with the unchanged mRNA expression of glucokinase. Thus, ZFPx rats are unable to further enhance their islet glucose metabolism in order to compensate for the increased insulin demand per islet following partial Px, but do not have a major defect in islet total glucose utilisation and oxidation.

The present study demonstrates that the islet triacylglycerol content of ZF-Px rats is unchanged, with a tendency to be decreased, thus excluding islet steatosis as a causal factor for the more moderate type 2 diabetes in this animal model. We have proposed that lipid metabolism and signalling are involved in beta cell compensation in ZF rat islets due to enhanced GL/FA cycling [29]. Thus, it was of interest to determine whether defects in islet lipid metabolism, short of causing steatosis, could be involved in beta cell failure in ZF-Px rats. Interestingly, $60 \% \mathrm{Px}$ in $\mathrm{ZL}$ and $\mathrm{ZF}$ rats was associated with an increase in lipolysis, suggesting that increased GL/FA cycling may be a process involved not only in the compensatory response to obesityassociated insulin resistance [39], but also in beta cell

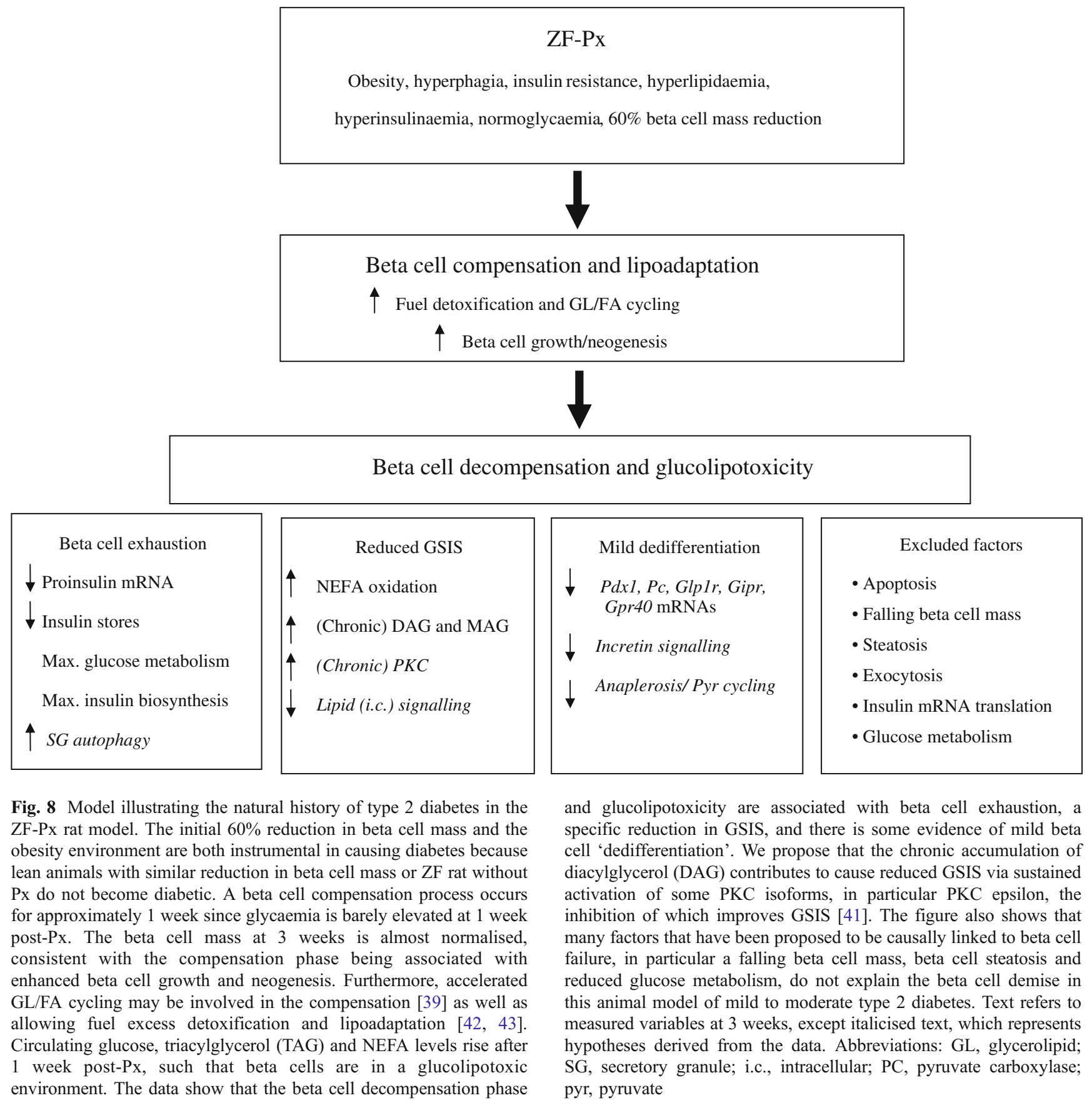


growth. However, a striking difference between the response of $\mathrm{ZF}$ and $\mathrm{ZL}$ islets to Px was the accumulation of mono- and diacylglycerol. Px in the ZL rats had no effect on esterification of palmitate into mono- and diacylglycerol, whereas in the ZF rats, it caused marked accumulation of both. Px in ZF rats was also associated with a 4.5 -fold increase in islet mRNA levels of $S c d 1$, which is implicated in lipid desaturation and strongly favours GL synthesis [40]. Thus, this clear difference in GL metabolism in response to Px in ZF compared with ZL rats could be dysfunctional. Diacylglycerol activates protein kinase C (PKC) enzymes and chronic activation of beta cell PKC with phorbol esters suppresses GSIS. In addition, the diacylglycerol-sensitive PKC epsilon plays an inhibitory role in GSIS [41]. Thus, it can be hypothesised that the reduced GSIS in ZF-Px islets may in part be due to chronic activation of specific PKC enzyme(s) as a result of diacylglycerol deposition. The role of intracellular monoacylglycerol in islet function has not been investigated. The question of whether monoacylglycerol accumulation is reflective of other lipid partitioning defects or more directly causes beta cell dysfunction warrants further investigation.

Islet fatty acid oxidation was increased by $60 \% \mathrm{Px}$ in $\mathrm{ZF}$ rats at the physiological glucose level of $8 \mathrm{mmol} / \mathrm{l}$. This could have negative effects for insulin secretion but be advantageous for islet survival. In accordance with the lipid signalling hypothesis of insulin secretion, increased fatty acid oxidation will favour the removal of cytosolic lipid signalling molecules, thus providing a possible explanation for the reduced GSIS. Fatty acid oxidation, however, could be a mechanism of detoxification of cellular lipid content and therefore could be protective, particularly in situations of increased GL/FA cycling. We have proposed a role for GL/FA cycling in the glucolipodetoxification process $[42,43]$. Very active GL/FA cycling, together with enhanced fat oxidation, may explain why ZF-Px islets did not accumulate triacylglycerol despite elevated glycaemia and circulating triacylglycerol levels amounting to glucolipotoxic conditions.

Finally, our mRNA expression studies suggest altered incretin signalling in ZF-Px islets, since the expression of Glp1r, Gipr and Ffrall (also known as Gpr40) was reduced. Reduced mRNA expression and protein content of the GLP-1 receptor has been observed in islets of ZDF and 90\% pancreatectomised diabetic rats [44]. Altered incretin signalling is thought to contribute to beta cell dysfunction and the current data are consistent with this view, at least with respect to the in vivo situation. However, reduced expression of these receptors does not provide an explanation for the defective GSIS of ZF-Px islets ex vivo. The reductions in mRNA expression of these receptors, in addition to that for $P d x l$ and proinsulin, may be consistent with some degree of islet beta cell 'dedifferentiation', which is also thought to be involved in late beta cell failure in type 2 diabetes [3].
In summary, and as illustrated in the model summarising the data (Fig. 8), hyperglycaemia in the ZF 60\% Px rat is due to islet beta cell dysfunction, particularly with respect to GSIS, rather than reduced beta cell mass or steatosis. The results are consistent with the view that regenerating beta cells are susceptible to dysfunction in a glucolipotoxic, insulin-resistant environment. Lack of steatosis in this moderate model may be due to active GL/FA cycling and increased fatty acid oxidation processes that are likely to favour glucolipodetoxification. The beta cell dysfunction in $60 \%$ ZF-Px rats is due to severe 'exhaustion' as characterised by marked reduction in stored insulin granules. As proinsulin biosynthesis is increased, the possibility of enhanced autophagy of insulin-containing vesicles warrants investigation. The dysfunction also involves defective signalling of GSIS. There is some evidence of defects in anaplerosis and GL metabolism that may be mechanistically involved, particularly as seen with the accumulation of monoand diacylglycerol associated with markedly increased $S c d 1$ expression and reduced $P c$ expression. There is also some evidence for mild beta cell 'dedifferentiation' including reduced expression of incretin receptors. The question of whether alterations in GL metabolism are mechanistically linked to beta cell regeneration, degranulation and exhaustion is yet to be answered.

Acknowledgements This work was supported by grants from the National Institutes of Health (DK56818, DK66635 and DK59851), American Diabetes Association, the Canadian Diabetes Association, the Canadian Institute of Health Research and the National Health and Medical Research Council (418077). The authors would like to thank G. Fergusson, R. Lussier, A. Gokin and A. Habibovic for their expert technical assistance. M. Prentki is the recipient of a Canadian chair in diabetes and metabolism. We thank V. Poitout for helpful discussions and critical review of the manuscript.

Duality of interest The authors declare that there is no duality of interest associated with this manuscript.

\section{References}

1. Kahn SE (2001) Clinical review 135: The importance of beta-cell failure in the development and progression of type 2 diabetes. $\mathrm{J}$ Clin Endocrinol Metab 86:4047-4058

2. Shulman GI (2000) Cellular mechanisms of insulin resistance. J Clin Invest 106:171-176

3. Prentki M, Nolan CJ (2006) Islet beta cell failure in type 2 diabetes. J Clin Invest 116:1802-1812

4. Garvey WT, Olefsky JM, Griffin J, Hamman RF, Kolterman OG (1985) The effect of insulin treatment on insulin secretion and insulin action in type II diabetes mellitus. Diabetes 34:222-234

5. Kosaka K, Kuzuya T, Akanuma Y, Hagura R (1980) Increase in insulin response after treatment of overt maturity-onset diabetes is independent of the mode of treatment. Diabetologia 18:23-28

6. Butler AE, Janson J, Bonner-Weir S, Ritzel R, Rizza RA, Butler PC (2003) Beta-cell deficit and increased beta-cell apoptosis in humans with type 2 diabetes. Diabetes 52:102-110 
7. Leahy JL, Bonner-Weir S, Weir GC (1988) Minimal chronic hyperglycemia is a critical determinant of impaired insulin secretion after an incomplete pancreatectomy. J Clin Invest 81:1407-1414

8. Matveyenko AV, Veldhuis JD, Butler PC (2006) Mechanisms of impaired fasting glucose and glucose intolerance induced by an approximate 50\% pancreatectomy. Diabetes 55:2347-2356

9. Bonner-Weir S, Trent DF, Weir GC (1983) Partial pancreatectomy in the rat and subsequent defect in glucose-induced insulin release. J Clin Invest 71:1544-1553

10. Rossetti L, Shulman GI, Zawalich W, DeFronzo RA (1987) Effect of chronic hyperglycemia on in vivo insulin secretion in partially pancreatectomized rats. J Clin Invest 80:1037-1044

11. Lee HC, Bonner-Weir S, Weir GC, Leahy JL (1989) Compensatory adaption to partial pancreatectomy in the rat. Endocrinology 124:1571-1575

12. Greenwood RH, Mahler RF, Hales CN (1976) Improvement in insulin secretion in diabetes after diazoxide. Lancet 1:444-447

13. Laedtke T, Kjems L, Porksen N et al (2000) Overnight inhibition of insulin secretion restores pulsatility and proinsulin/insulin ratio in type 2 diabetes. Am J Physiol Endocrinol Metab 279:E520-E528

14. Leahy JL, Bumbalo LM, Chen C (1994) Diazoxide causes recovery of beta-cell glucose responsiveness in $90 \%$ pancreatectomized diabetic rats. Diabetes 43:173-179

15. Zhou YP, Grill VE (1994) Long-term exposure of rat pancreatic islets to fatty acids inhibits glucose-induced insulin secretion and biosynthesis through a glucose fatty acid cycle. J Clin Invest 93:870-876

16. Hagman DK, Hays LB, Parazzoli SD, Poitout V (2005) Palmitate inhibits insulin gene expression by altering PDX-1 nuclear localization and reducing MafA expression in isolated rat islets of Langerhans. J Biol Chem 280:32413-32418

17. Laybutt DR, Preston AM, Akerfeldt MC et al (2007) Endoplasmic reticulum stress contributes to beta cell apoptosis in type 2 diabetes. Diabetologia 50:752-763

18. Maedler K, Spinas GA, Dyntar D, Moritz W, Kaiser N, Donath MY (2001) Distinct effects of saturated and monounsaturated fatty acids on beta-cell turnover and function. Diabetes 50:69-76

19. El-Assaad W, Buteau J, Peyot ML et al (2003) Saturated fatty acids synergize with elevated glucose to cause pancreatic beta-cell death. Endocrinology 144:4154-4163

20. Prentki M, Corkey BE (1996) Are the beta-cell signaling molecules malonyl-CoA and cystolic long-chain acyl-CoA implicated in multiple tissue defects of obesity and NIDDM? Diabetes 45:273-283

21. Lee Y, Hirose H, Ohneda M, Johnson JH, McGarry JD, Unger RH (1994) Beta-cell lipotoxicity in the pathogenesis of non-insulindependent diabetes mellitus of obese rats: impairment in adipocytebeta-cell relationships. Proc Natl Acad Sci U S A 91:10878-10882

22. Zhou YP, Berggren PO, Grill V (1996) A fatty acid-induced decrease in pyruvate dehydrogenase activity is an important determinant of beta-cell dysfunction in the obese diabetic $\mathrm{db} / \mathrm{db}$ mouse. Diabetes 45:580-586

23. Kaiser N, Nesher R, Donath MY et al (2005) Psammomys obesus, a model for environment-gene interactions in type 2 diabetes. Diabetes 54(Suppl 2):S137-S144

24. Laybutt DR, Sharma A, Sgroi DC, Gaudet J, Bonner-Weir S, Weir GC (2002) Genetic regulation of metabolic pathways in betacells disrupted by hyperglycemia. J Biol Chem 277:10912-10921

25. Koyama M, Wada R, Sakuraba H, Mizukami H, Yagihashi S (1998) Accelerated loss of islet beta cells in sucrose-fed GotoKakizaki rats, a genetic model of non-insulin-dependent diabetes mellitus. Am J Pathol 153:537-545
26. Liu YQ, Jetton TL, Leahy JL (2002) Beta-cell adaptation to insulin resistance. Increased pyruvate carboxylase and malatepyruvate shuttle activity in islets of nondiabetic Zucker fatty rats. J Biol Chem 277:39163-39168

27. Liu YQ, Nevin PW, Leahy JL (2000) Beta-cell adaptation in $60 \%$ pancreatectomy rats that preserves normoinsulinemia and normoglycemia. Am J Physiol Endocrinol Metab 279:E68-E73

28. Jetton TL, Lausier J, LaRock K et al (2005) Mechanisms of compensatory beta-cell growth in insulin-resistant rats: roles of Akt kinase. Diabetes 54:2294-2304

29. Nolan CJ, Leahy JL, Delghingaro-Augusto V et al (2006) Beta cell compensation for insulin resistance in Zucker fatty rats: increased lipolysis and fatty acid signalling. Diabetologia 49:2120-2130

30. Enoch HG, Catala A, Strittmatter P (1976) Mechanism of rat liver microsomal stearyl-CoA desaturase. Studies of the substrate specificity, enzyme-substrate interactions, and the function of lipid. J Biol Chem 251:5095-5103

31. Kershaw EE, Hamm JK, Verhagen LA, Peroni O, Katic M, Flier JS (2006) Adipose triglyceride lipase: function, regulation by insulin, and comparison with adiponutrin. Diabetes 55:148-157

32. Hosokawa YA, Hosokawa H, Chen C, Leahy JL (1996) Mechanism of impaired glucose-potentiated insulin secretion in diabetic $90 \%$ pancreatectomy rats. Study using glucagon-like peptide-1 (7-37). J Clin Invest 97:180-186

33. Fery F, Balasse EO (1994) Glucose metabolism during the starved-to-fed transition in obese patients with NIDDM. Diabetes 43:1418-1425

34. Rhodes CJ, Lucas CA, Halban PA (1987) Glucose stimulates the biosynthesis of rat I and II insulin to an equal extent in isolated pancreatic islets. FEBS Lett 215:179-182

35. Wicksteed B, Alarcon C, Briaud I, Lingohr MK, Rhodes CJ (2003) Glucose-induced translational control of proinsulin biosynthesis is proportional to preproinsulin mRNA levels in islet beta-cells but not regulated via a positive feedback of secreted insulin. J Biol Chem 278:42080-42090

36. Halban PA, Wollheim CB (1980) Intracellular degradation of insulin stores by rat pancreatic islets in vitro. An alternative pathway for homeostasis of pancreatic insulin content. J Biol Chem 255:6003-6006

37. Marsh BJ, Soden C, Alarcon C et al (2007) Regulated autophagy controls hormone content in secretory-deficient pancreatic endocrine beta-cells. Mol Endocrinol 21:2255-2269

38. Ebato C, Uchida T, Arakawa M et al (2008) Autophagy is important in islet homeostasis and compensatory increase of beta cell mass in response to high-fat diet. Cell Metab 4:325-332

39. Nolan CJ, Madiraju MS, Delghingaro-Augusto V, Peyot ML, Prentki M (2006) Fatty acid signaling in the beta-cell and insulin secretion. Diabetes 55(Suppl 2):S16-S23

40. Cohen P, Ntambi JM, Friedman JM (2003) Stearoyl-CoA desaturase-1 and the metabolic syndrome. Curr Drug Targets Immune Endocr Metabol Disord 3:271-280

41. Schmitz-Peiffer C, Laybutt DR, Burchfield JG et al (2007) Inhibition of PKCepsilon improves glucose-stimulated insulin secretion and reduces insulin clearance. Cell Metab 6:320-328

42. Prentki M, Madiraju SR (2008) Glycerolipid metabolism and signaling in health and disease. Endocr Rev 29:647-676

43. Nolan CJ, Prentki M (2008) The islet beta-cell: fuel responsive and vulnerable. Trends Endocrinol Metab 19:285-291

44. Xu G, Kaneto H, Laybutt DR et al (2007) Downregulation of GLP-1 and GIP receptor expression by hyperglycemia: possible contribution to impaired incretin effects in diabetes. Diabetes $56: 1551-1558$ 